\title{
Effects of Trypsin on Cytosolic Calcium Levels in the Rat Aortic Endothelium
}

\author{
Daijiro KANEKO ${ }^{1)}$, Hiroyuki KOMATSU ${ }^{1)}$, Takashi OHAMA ${ }^{1)}$ and Koichi SATO ${ }^{1) *}$ \\ ${ }^{1)}$ Department of Veterinary Pharmacology, Yamaguchi University, 1677-1 Yoshida, Yamaguchi 753-8515, Japan.
}

(Received 16 February 2011/Accepted 24 March 2011/Published online in J-STAGE 7 April 2011)

ABSTRACT. The effect of trypsin on vascular tone and the cytosolic calcium concentration $\left(\left[\mathrm{Ca}^{2+}\right]_{\mathrm{i}}\right)$ of endothelial and smooth muscle cells were examined in the rat aorta. A calcium indicator, fura-PE3, was used to measure $\left[\mathrm{Ca}^{2+}\right]_{\mathrm{i}}$ simultaneously with vascular tone. In the endothelium-intact rat aorta, carbachol and trypsin increased $\left[\mathrm{Ca}^{2+}\right]_{\mathrm{i}}$ in a dose-dependent manner. In the endothelium-denuded rat aorta, carbachol did not change $\left[\mathrm{Ca}^{2+}\right]_{\mathrm{i}}$, but trypsin slightly increased it. Addition of trypsin to the norepinephrine-stimulated rat aorta relaxed the muscle with an additional increase in $\left[\mathrm{Ca}^{2+}\right]_{\mathrm{i}}$. Under calcium-free conditions, trypsin induced a transient increase in $\left[\mathrm{Ca}^{2+}\right]_{\mathrm{i}}$. Trypsininduced endothelium-dependent relaxation was inhibited by preincubation with 1-NMMA, an endothelial NO synthase inhibitor, U-73122, a phospholipase $\mathrm{C}$ inhibitor, cyclopiazonic acid, a sarcoplasmic/endoplasmic reticulum $\mathrm{Ca}^{2+}$-ATPase blocker, and lanthanum, a nonselective $\mathrm{Ca}^{2+}$ channel blocker. However, indomethacin, a nonselective cyclooxygenase inhibitor, and SKF-96365, a store-operated Ca ${ }^{2+}-$ channel blocker, had no effect on the trypsin-induced relaxation. These results suggest that trypsin increases $\left[\mathrm{Ca}^{2+}\right]_{\mathrm{i}}$ in the endothelial cells through SKF-96365-insensitive $\mathrm{Ca}^{2+}$ channels and regulates the release of $\mathrm{NO}$, which results in relaxation of the rat aorta. KEY WORDS: cytosolic calcium level, endothelium derived relaxation, trypsin.

Trypsin is one of the proteases excreted from the pancreas. It has many physiological and pathophysiological roles such as a digestive enzyme and for vascular relaxation and myometrial contraction $[6,10,14]$. Trypsin causes endothelium-dependent vasorelaxation in many types of blood vessels including the rat aorta, rat superior mesenteric artery and porcine coronary artery $[1,9,14]$. It has also been reported that the relaxation is due to nitric oxide and hyperpolarizing factors $[4,14]$.

It is widely known that trypsin activates protease-activated receptor (PAR) 2 under physiological conditions [16]. The PAR family is an unique family of G-protein-coupled seven-transmembrane receptors that are activated by proteolytic cleavage of the extracellular N-terminal domain $[5,7$, $16,22]$. Among the PAR family, the function of PAR2 has been widely studied, and this receptor is known to be involved in hypertension, inflammation, allergies, hemorrhaging, exocrine activities and intestinal ion transport [11, $15,17]$.

In the porcine coronary artery, trypsin induced an endothelium-dependent relaxation and a decrease in the cytosolic calcium concentration $\left(\left[\mathrm{Ca}^{2+}\right]_{\mathrm{i}}\right)$ in smooth muscle cells [13]. In the porcine arterial valve, trypsin induced a transient elevation of $\left[\mathrm{Ca}^{2+}\right]_{\mathrm{i}}$ of endothelial cells [14]. However, the authors of that report did not measure the relaxing effect of trypsin simultaneously with the changes in $\left[\mathrm{Ca}^{2+}\right]_{\mathrm{i}}$ in endothelial cells. In a previous study [19], we measured the endothelium-dependent relaxation induced by carbachol simultaneously with the changes in endothelial $\left[\mathrm{Ca}^{2+}\right]_{\mathrm{i}}$ in the rat aorta. The present study thus aimed to assess the relationship of trypsin-induced smooth muscle relaxation and

\footnotetext{
* Correspondence to: SAto, K., Department of Veterinary Pharmacology, Yamaguchi University, 1677-1 Yoshida, Yamaguchi 753-8515, Japan.

e-mail: k-sato@yamaguchi-u.ac.jp
}

the changes in endothelial $\left[\mathrm{Ca}^{2+}\right]_{\mathrm{i}}$ by using the simultaneous measurement technique.

\section{MATERIALS AND METHODS}

Tissue preparation: The animals were maintained in compliance with the guidelines of the Animal Care and Use Committee of Yamaguchi University. Male Wistar rats weighing 150-200 g were anaesthetized using ether and exsanguinated. The thoracic aorta was isolated and cut into helical strips (2-3 mm wide and 8-10 $\mathrm{mm}$ length) in normal physiological solution (in $\mathrm{mM}$ : $\mathrm{NaCl} 121.0, \mathrm{KCl} 5.4, \mathrm{MgCl}_{2}$ 1.0, $\mathrm{CaCl}_{2}$ 1.8, glucose 5.5, Tris 25, $\mathrm{pH} 7.4$, with $\mathrm{HCl}$ ). $\mathrm{Ca}^{2+}$-free solution was made by adding $0.2 \mathrm{mM}$ EGTA instead of $\mathrm{CaCl}_{2}$ into the normal physiological solution. In some experiments, the endothelial cells were removed by gently rubbing with a cotton swab.

Simultaneous measurement of the $\left[\mathrm{Ca}^{2+}\right]_{i}$ with muscle contraction in the rat aorta: $\mathrm{A} \mathrm{Ca}^{2+}$ indicator, fura-PE3, was used to measure $\left[\mathrm{Ca}^{2+}\right]_{\mathrm{i}}$ simultaneously with muscle tension as reported previously $[19,20]$. In brief, muscle strips were loaded with $5 \mu \mathrm{M}$ acetoxymethyl ester of fura-PE3 for $3-5$ $\mathrm{hr}$ in the presence of $0.02 \%$ cremophor EL at room temperature and then placed in a tissue bath containing the normal physiological solution aerated with $100 \% \mathrm{O}_{2}$ at $37^{\circ} \mathrm{C}$. The muscle strip was illuminated from the side of the endothelial monolayer alternately with 340 and $380 \mathrm{~nm}$ light, and the amount of $500 \mathrm{~nm}$ fluorescence induced by $340 \mathrm{~nm}$ excitation (F340) or that induced by $380 \mathrm{~nm}$ excitation (F380) was detected with a spectrophotometer (CAF-110, Japan Spectroscopic, Tokyo, Japan). The ratio of F340/F380 was monitored as the change in $\left[\mathrm{Ca}^{2+}\right]_{i}$. The muscle contraction was measured simultaneously with $\left[\mathrm{Ca}^{2+}\right]_{\mathrm{i}}$. A resting tension of $10 \mathrm{mN}$ was applied to each muscle strip.

Chemicals: The chemicals used were as follows: carba- 
chol, norepinephrine and fura-PE3 (Sigma, Tokyo, Japan); EDTA (Dojindo Laboratories, Kumamoto, Japan); and other chemicals (Wako Pure Chemical Industries, Osaka, Japan).

Statistical analyses: Results were expressed as means \pm standard error of the mean (SEM). Statistical evaluations of data were performed using paired or unpaired Student's $t$ tests for comparisons between 2 groups and one-way analysis of variance followed by the Tukey test for comparisons among $\geq 3$ groups using the GraphPad Prism software (GraphPad Software, San Diego, CA, U.S.A.). Values of $P<0.05$ were considered statistically significant.

\section{RESULTS}

Effects of carbachol and trypsin on $\left[\mathrm{Ca}^{2+}\right]_{\mathrm{i}}$ and contractile tension in the resting rat aorta: As shown in Fig. 1, 65.4-mM $\mathrm{KCl}$ induced a sustained increase in $\left[\mathrm{Ca}^{2+}\right]_{\mathrm{i}}$ and muscle tension in the endothelium-intact (A) and endotheliumdenuded (B) rat aorta. After washing the muscle with normal physiological solution, addition of $3 \mu \mathrm{M}$ carbachol or $0.3 \mu \mathrm{M}$ trypsin induced a sustained increase in $\left[\mathrm{Ca}^{2+}\right]_{\mathrm{i}}$ with a slight decrease in the resting tension of the endotheliumintact aorta (Fig. 1A). In endothelium-denuded vessels, carbachol did not change $\left[\mathrm{Ca}^{2+}\right]_{\mathrm{i}}$ and muscle contraction, but trypsin induced a small increase in $\left[\mathrm{Ca}^{2+}\right]_{i}$ without any change in resting tension (Fig. 1B). Addition of carbachol $(0.1-10 \mu \mathrm{M})$ and trypsin $(1-100 \mathrm{nM})$ increased $\left[\mathrm{Ca}^{2+}\right]_{\mathrm{i}}$ in a dose-dependent manner in the endothelium-intact preparation (Fig. 2A and 2B). In endothelium-denuded vessels, a higher concentration of trypsin $(0.1-10 \mu \mathrm{M})$ induced a more apparent increase in $\left[\mathrm{Ca}^{2+}\right]_{\mathrm{i}}$ (Fig. $\left.2 \mathrm{C}\right)$, but carbachol $(10 \mu \mathrm{M})$ did not have any effect on $\left[\mathrm{Ca}^{2+}\right]_{i}$ (data not shown).

Effect of trypsin on $\left[\mathrm{Ca}^{2+}\right]_{i}$ and contraction in the rat aorta precontracted with norepinephrine: Norepinephrine $(0.3 \mu \mathrm{M})$ induced a sustained increase in $\left[\mathrm{Ca}^{2+}\right]_{\mathrm{i}}$ and muscle tension in both of the endothelium-intact and endotheliumdenuded rat aorta (Fig. 3A and 3B). Addition of $0.3 \mu \mathrm{M}$ trypsin in the presence of norepinephrine caused a rapid and sustained increase in $\left[\mathrm{Ca}^{2+}\right]_{\mathrm{i}}$ and rapid relaxation in the endothelium-intact preparation (Fig. 3A). By contrast, trypsin had a small effect on $\left[\mathrm{Ca}^{2+}\right]_{\mathrm{i}}$ without any changes in contraction in endothelium-denuded vessels (Fig. 3B).

Effect of trypsin on $\left[\mathrm{Ca}^{2+}\right]_{i}$ and contraction in $\mathrm{Ca}^{2+}$-free solution: After observing $65.4-\mathrm{mM} \mathrm{KCl-induced} \mathrm{changes,}$ the external solution was replaced with a $\mathrm{Ca}^{2+}$-free solution, which resulted in a rapid decrease in $\left[\mathrm{Ca}^{2+}\right]_{\mathrm{i}}$ and a slight decrease in resting tension (Fig. 3C). Addition of $0.3 \mu \mathrm{M}$ trypsin induced a transient increase in $\left[\mathrm{Ca}^{2+}\right]_{i}$ without any changes in muscle tension in the endothelium-intact preparation. However, trypsin showed no effect on $\left[\mathrm{Ca}^{2+}\right]_{i}$ in the endothelium-denuded preparation (data not shown).

Effects of inhibitors on endothelium-dependent relaxation induced by trypsin: In the presence of $0.3 \mu \mathrm{M}$ norepinephrine, trypsin (0.01-100 nM) induced dose-dependent relaxation of the endothelium-intact rat aorta (Fig. 4). In the vessels preincubated with a NO synthase inhibitor, 1-
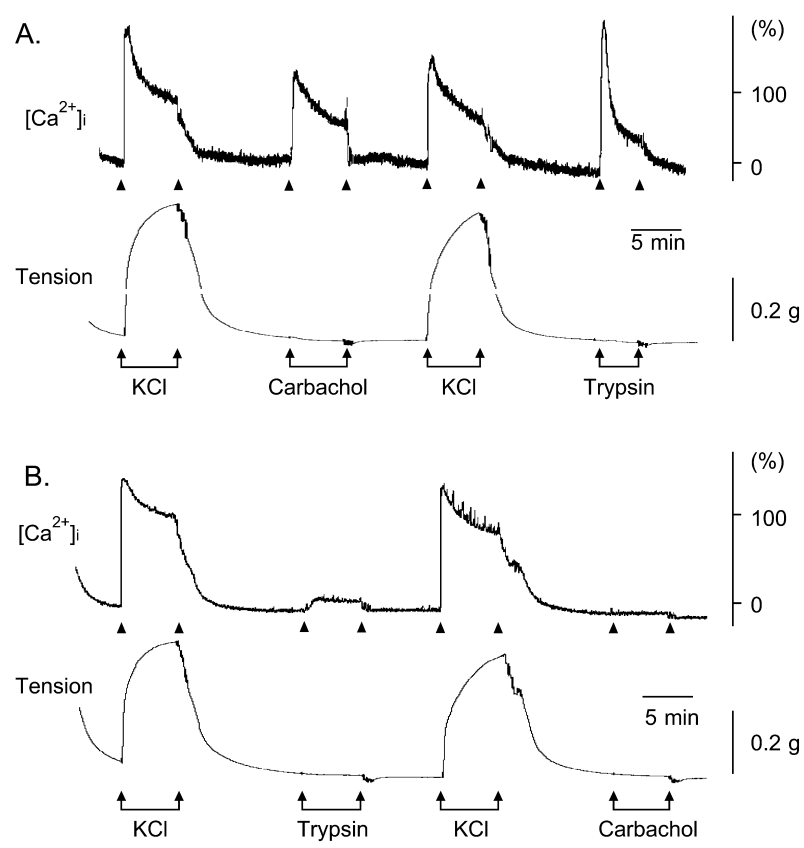

Fig. 1. Effects of carbachol and trypsin on $\left[\mathrm{Ca}^{2+}\right]_{\mathrm{i}}$ (upper trace) and contractile tension (lower trace) in the endothelium-intact (A) and endothelium-denuded (B) rat aorta. After the effects of 65.4-mM KCl were examined, carbachol $(3 \mu \mathrm{M})$ or trypsin $(0.3$ $\mu \mathrm{M})$ was added. The tonic level of $\mathrm{KCl}$-induced $\left[\mathrm{Ca}^{2+}\right]_{\mathrm{i}}$ was defined as $100 \%$.
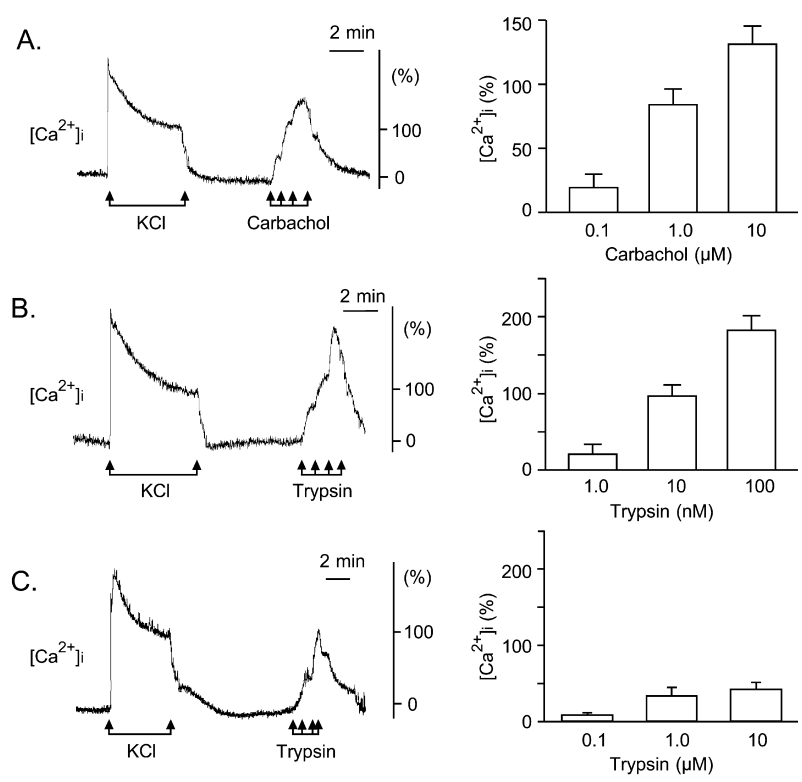

Fig. 2. Dose-dependent effects of carbachol and trypsin on $\left[\mathrm{Ca}^{2+}\right]_{\mathrm{i}}$ in the endothelium-intact and endothelium-denuded rat aorta. Typical results are shown in left panel. After the effects of 65.4$\mathrm{mM} \mathrm{KCl}$ were examined, carbachol $(0.1-10 \mu \mathrm{M}$; A) or trypsin (1-100 nM; B) was added cumulatively to the endotheliumintact preparations. Higher concentrations of trypsin (0.1-10 $\mu \mathrm{M}$; C) were applied to the endothelium-denuded preparation. Analytical results are shown in the right panels. The tonic level of $\mathrm{KCl}$-induced $\left[\mathrm{Ca}^{2+}\right]_{i}$ was defined as $100 \%(n=4-13)$. 

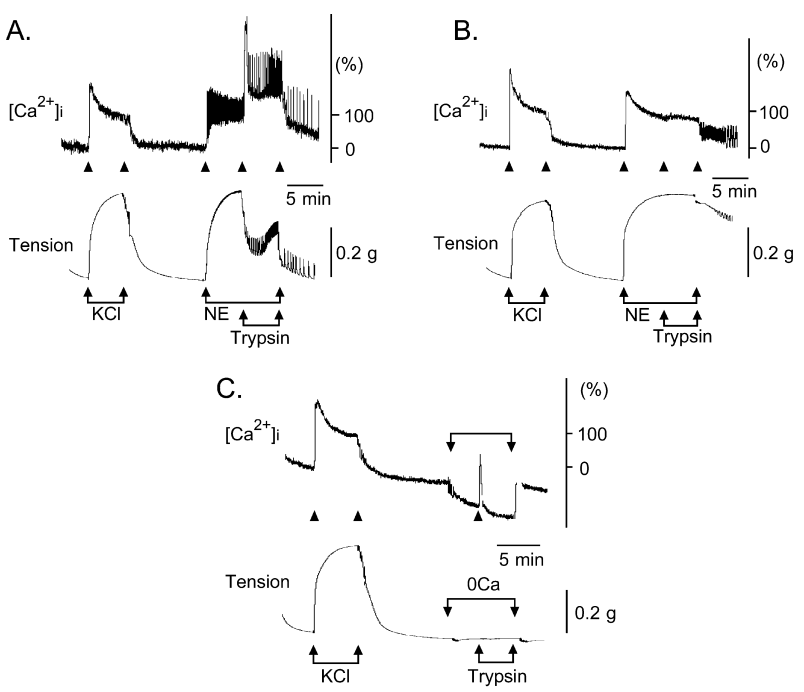

Fig. 3. Effect of trypsin on $\left[\mathrm{Ca}^{2+}\right]_{\mathrm{i}}$ (upper trace) and contractile tension (lower trace) of the rat aorta. In the presence of norepinephrine (NE, $0.3 \mu \mathrm{M})$, trypsin $(0.3 \mu \mathrm{M})$ was applied to the endothelium-intact (A) and endothelium-denuded (B) rat aorta. Trypsin $(0.3 \mu \mathrm{M})$ was applied in $\mathrm{Ca}^{2+}$-free solution (0Ca) (C). The tonic level of $65.4-\mathrm{mM}-\mathrm{KCl}$-induced $\left[\mathrm{Ca}^{2+}\right]_{\mathrm{i}}$ was defined as $100 \%$.

NMMA (200 $\mu \mathrm{M})$, for $20 \mathrm{~min}$, trypsin-induced relaxation was strongly inhibited (Fig. 4A). Pretreatment with indomethacin $(10 \mu \mathrm{M})$ for $20 \mathrm{~min}$, however, had no effect on trypsin-induced relaxation (Fig. 4B). Preincubation with a specific inhibitor of sarcoplasmic/endoplasmic reticulum $\mathrm{Ca}^{2+}$-ATPase, cyclopiazonic acid $(10 \mu \mathrm{M})$, or an inhibitor of phospholipase C, U-73122 $(5 \mu \mathrm{M})$, for 10 min inhibited trypsin-induced relaxation (Fig. 4C and 4D). Finally, we examined the effects of calcium channel blockers on trypsin-induced relaxation. The addition of lanthanum $(0.1$ and $0.3 \mathrm{mM}$ for $10 \mathrm{~min}$ ), a nonselective $\mathrm{Ca}^{2+}$ channel inhibitor, inhibited trypsin-induced relaxation in a dose-dependent manner (Fig. 4E). However, treatment with an inhibitor of store-operated $\mathrm{Ca}^{2+}$-channel, SKF-96365 (10 $\mu \mathrm{M})$, for $10 \mathrm{~min}$ did not change the dose-dependent relaxation induced by trypsin (Fig. 4F).

\section{DISCUSSION}

In the present study, the trypsin-induced changes in $\left[\mathrm{Ca}^{2+}\right]_{\mathrm{i}}$ of endothelial cells were simultaneously measured with the changes in the mechanical responses of smooth muscle in the rat aorta.

We have previously reported a method of measuring the endothelial and/or smooth muscle $\left[\mathrm{Ca}^{2+}\right]_{\mathrm{i}}$ simultaneously with muscle contraction by using $\mathrm{Ca}^{2+}$-indicator fura-2 [1820]. It has been reported that, in endothelium-intact vessels, the detected fluorescent intensity of a calcium indicator is attributed to that from endothelial cells and also from smooth muscle cells [20]. In our method, it is possible to
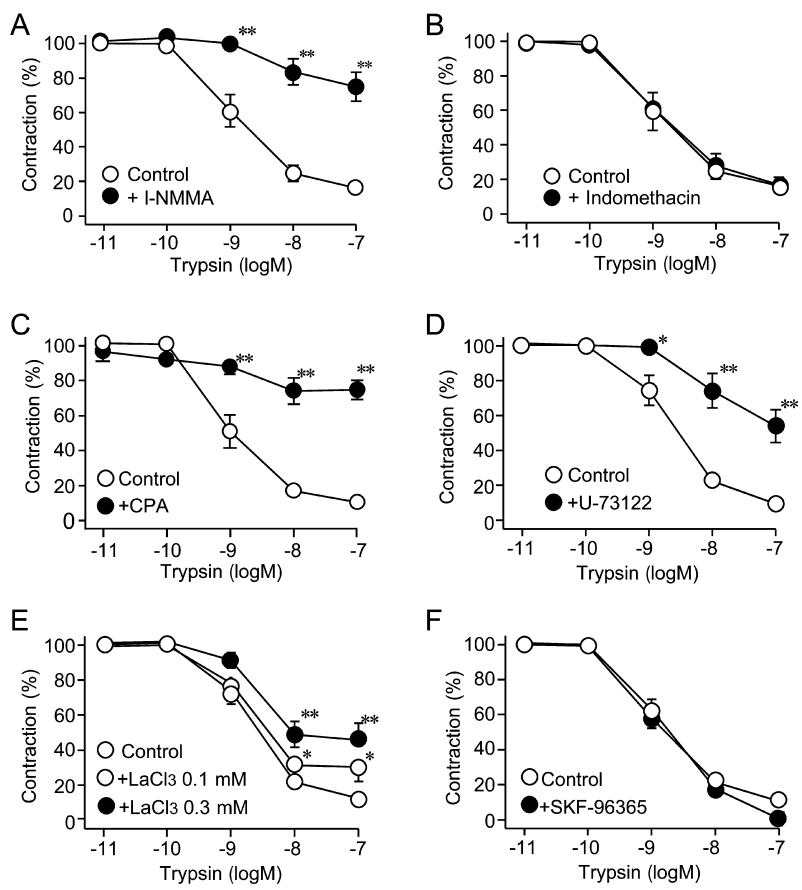

Fig. 4. Effects of inhibitors on trypsin-induced relaxation. Norepinephrine $(0.3 \mu \mathrm{M})$ was added $20 \mathrm{~min}$ after application of 1NMMA (200 $\mu \mathrm{M}, \mathrm{A})$ or indomethacin $(10 \mu \mathrm{M}, \mathrm{B})$. Cyclopiazonic acid (CPA; $10 \mu \mathrm{M}, \mathrm{C}), \mathrm{U}-73122(5 \mu \mathrm{M}, \mathrm{D}), \mathrm{LaCl}_{3}(0.1$ or $0.3 \mathrm{mM}, \mathrm{E})$ or SKF-96365 $(10 \mu \mathrm{M}, \mathrm{F})$ was applied $10 \mathrm{~min}$ before addition of norepinephrine. A norepinephrine-induced contraction just before the addition of trypsin $(0.1 \mu \mathrm{M})$ was defined as $100 \%$. *, **: statistical significance at the level of $P<0.05$ and $P<0.01$ vs. the control, respectively ( $\mathrm{n}=6-11)$.

detect $\left[\mathrm{Ca}^{2+}\right]_{\mathrm{i}}$ only from the endothelial cells by using selective agonists for the endothelial cells such as carbachol and histamine in the rat aorta [19]. In this study, we observed that addition of trypsin and carbachol to the endotheliumintact preparation in a resting state induced a dose-dependent increase in $\left[\mathrm{Ca}^{2+}\right]_{\mathrm{i}}$ (Figs. 1A, 2A and 2B). In the endothelium-denuded preparations, carbachol had no effect on $\left[\mathrm{Ca}^{2+}\right]_{\mathrm{i}}$, but a higher concentration of trypsin induced a small but apparent increase in $\left[\mathrm{Ca}^{2+}\right]_{\mathrm{i}}$ without muscle contraction. Trypsin activates PAR2 [16], which was expressed in both endothelial cells and smooth muscle cells of rat blood vessels [3]. These finding suggest that trypsin increases $\left[\mathrm{Ca}^{2+}\right]_{\mathrm{i}}$ not only in endothelial cells but also in smooth muscle cells in the rat aorta. In endothelium-denuded preparations, 0.1 $\mu \mathrm{M}$ trypsin induced a small increase in $\left[\mathrm{Ca}^{2+}\right]_{\mathrm{i}}(8.2 \pm 0.7 \%)$, but the same concentration of trypsin induced a marked increase in $\left[\mathrm{Ca}^{2+}\right]_{\mathrm{i}}(183.5 \pm 11.3 \%)$ in endothelium-intact preparations. These results suggested that the sensitivity of smooth muscle cells for trypsin is less than that of endothelial cells. Because, to elicit smooth muscle contraction, $\left[\mathrm{Ca}^{2+}\right]_{\mathrm{i}}$ should be increased to more than the threshold level [19], I the present experiments, the level of trypsin-induced $\left[\mathrm{Ca}^{2+}\right]_{\mathrm{i}}$ in rat aortic smooth muscle cells may not have been 
enough to cause contraction. Therefore, it seems likely that the trypsin-induced effects are mainly mediated by the endothelial cells of the rat aorta.

We have previously shown that carbachol and histamine induce an additional increase in $\left[\mathrm{Ca}^{2+}\right]_{\mathrm{i}}$ in the endotheliumintact rat aorta precontracted with norepinephrine [20]. Furthermore, it was also demonstrated that there was a positive correlation between the increase in $\left[\mathrm{Ca}^{2+}\right]_{\mathrm{i}}$ in endothelial cells and muscle relaxation [19]. In the present experiments, trypsin induced a marked increase in $\left[\mathrm{Ca}^{2+}\right]_{\mathrm{i}}$ with relaxation of the rat aorta precontracted with norepinephrine (Fig. 3A). It was reported that NO decreased $\left[\mathrm{Ca}^{2+}\right]_{\mathrm{i}}$ of smooth muscle cells to induce relaxation $[2,20]$. In the endothelium-denuded preparations precontracted with norepinephrine, trypsin induced a small increase in $\left[\mathrm{Ca}^{2+}\right]_{i}$ without any changes in muscle contraction (Fig. 3B). This result suggests that the trypsin-induced additional increase in $\left[\mathrm{Ca}^{2+}\right]_{\mathrm{i}}$ is mainly due to the increase in endothelial $\left[\mathrm{Ca}^{2+}\right]_{\mathrm{i}}$, which regulates the endothelium-dependent relaxation.

In the porcine arterial valve, it has been reported that trypsin induced a transient increase in $\left[\mathrm{Ca}^{2+}\right]_{\mathrm{i}}$ either in the presence or absence of extracellular $\mathrm{Ca}^{2+}$ [14]. The authors concluded that the trypsin-induced $\left[\mathrm{Ca}^{2+}\right]_{\mathrm{i}}$ elevation was mediated mainly by the $\mathrm{Ca}^{2+}$ release [14]. Consistent with these findings, we observed that trypsin induced a transient increase in $\left[\mathrm{Ca}^{2+}\right]_{\mathrm{i}}$ under $\mathrm{Ca}^{2+}$-free conditions (Fig. 3C). In normal physiological solution, however, trypsin induced two-phase changes of $\left[\mathrm{Ca}^{2+}\right]_{i}$, a first transient phase and second tonic phase (Fig. 1A). In a previous study, carbachol or histamine induced a transient increase in $\left[\mathrm{Ca}^{2+}\right]_{\mathrm{i}}$ only under $\mathrm{Ca}^{2+}$-free conditions [19]. These results suggest that the trypsin-induced $\left[\mathrm{Ca}^{2+}\right]_{\mathrm{i}}$ elevation is mediated by the $\mathrm{Ca}^{2+}$ release and $\mathrm{Ca}^{2+}$ influx. In the present study, trypsininduced relaxation was attenuated by 1-NMMA, but not by indomethacin (Fig. 4A and 4B). In porcine coronary artery, 1-NORG, another NOS inhibitor, attenuated trypsin-induced relaxation [14]. These results suggest that trypsin-induced endothelium-dependent relaxation is mainly mediated by NO.

It is well known that the agonist-induced $\mathrm{Ca}^{2+}$ influx in endothelial cells is mediated by the store-operated cation channels (SOCs) that are activated by inositol 1,4,5-trisphosphate $\left(\mathrm{IP}_{3}\right)$-sensitive $\mathrm{Ca}^{2+}$-store depletion [21]. It was also reported that trypsin-induced $\mathrm{Cl}^{-}$secretion from the colonic epithelium depends on intracellular $\mathrm{Ca}^{2+}$ signaling mediated by $\mathrm{Ca}^{2+}$ release from intracellular stores and extracellular $\mathrm{Ca}^{2+}$ entry [13]. We revealed that trypsin-induced endothelium-dependent relaxation was inhibited by cyclopiazonic acid, U-73122, and lanthanum (Fig. 4C-E). These results suggest that the increase in $\left[\mathrm{Ca}^{2+}\right]_{\mathrm{i}}$ induced by trypsin is achieved by generation of $\mathrm{IP}_{3}$, release of stored intracellular $\mathrm{Ca}^{2+}$ and $\mathrm{Ca}^{2+}$ entry through plasma membrane channels in endothelial cells. On the other hand, SKF-96365 did not change the trypsin-induced relaxation (Fig. 4F). Although SKF-96365 is widely used as a SOCs-inhibitor [23, 24], it was also reported that agonist-induced store-operated $\mathrm{Ca}^{2+}$ entry in several types of cells was not inhibited by treatment with SKF-96365 $[8,12]$, suggesting the existence of SKF96365-insensitive store-operated $\mathrm{Ca}^{2+}$ channels. These results suggest that trypsin likely induces $\mathrm{Ca}^{2+}$ entry through SKF-96365-insensitive store-operated $\mathrm{Ca}^{2+}$ channels.

In conclusion, we revealed that trypsin increases $\left[\mathrm{Ca}^{2+}\right]_{\mathrm{i}}$ in endothelial cells through the store-operated $\mathrm{Ca}^{2+}$ channel that is insensitive to SKF-96365 and that synthesis of NO, which results in relaxation of the rat aorta, is regulated by $\left[\mathrm{Ca}^{2+}\right]_{\mathrm{i}}$ in endothelial cells of the rat aorta.

ACKNOWLEDGMENT. This work was supported by a Grant-in-Aid for Scientific Research from the Japanese Ministry of Education, Culture, Sports, Science and Technology.

\section{REFERENCES}

1. Aman, M., Hirano, M., Kanaide, H. and Hirano, K. 2010. Upregulation of proteinase-activated receptor-2 and increased response to trypsin in endothelial cells after exposure to oxidative stress in rat aortas. J. Vasc. Res. 47: 494-506.

2. Bolz, S. S., de Wit, C. and Pohl, U. 1999. Endothelium-derived hyperpolarizing factor but not $\mathrm{NO}$ reduces smooth muscle $\mathrm{Ca}^{2+}$ during acetylcholine-induced dilation of microvessels. $\mathrm{Br} . \mathrm{J}$. Pharmacol. 128: 124-134.

3. Cicala, C., Pinto, A., Bucci, M., Sorrentino, R., Walker, B., Harriot, P., Cruchley, A., Kapas, S., Howells, G. L. and Cirino, G. 1999. Protease-activated receptor-2 involvement in hypotension in normal and endotoxemic rats in vivo. Circulation 99: 2590-2597.

4. Hamilton, J. R. and Cocks, T. M. 2000. Heterogeneous mechanisms of endothelium-dependent relaxation for thrombin and peptide activators of protease-activated receptor- 1 in porcine isolated coronary artery. Br. J. Pharmacol. 130: 181-188.

5. Hollenberg, M. D., Saifeddine, M. and al-Ani, B. 1996. Proteinase-activated receptor-2 in rat aorta: structural requirements for agonist activity of receptor-activating peptides. Mol. Pharmacol. 49: 229-233.

6. Hwa, J. J., Ghibaudi, L., Williams, P., Chintala, M., Zhang, R., Chatterjee, M. and Sybertz, E. 1996. Evidence for the presence of a proteinase-activated receptor distinct from the thrombin receptor in vascular endothelial cells. Circ. Res. 78: 581-588.

7. Ishihara, H., Connolly, A. J., Zeng, D., Kahn, M. L., Zheng, Y. W., Timmons, C., Tram, T. and Coughlin, S. R. 1997. Protease-activated receptor 3 is a second thrombin receptor in humans. Nature 386: 502-506.

8. Iwamuro, Y., Miwa, S., Minowa, T., Enoki, T., Zhang, X. F., Ishikawa, M., Hashimoto, N. and Masaki, T. 1998. Activation of two types of $\mathrm{Ca}^{2+}$-permeable nonselective cation channel by endothelin-1 in A7r5 cells. Br. J. Pharmacol. 124: 1541-1549.

9. Kawabata, A., Kubo, S., Nakaya, Y., Ishiki, T., Kuroda, R., Sekiguchi, F., Kawao, N. and Nishikawa, H. 2004. Distinct roles for protease-activated receptors 1 and 2 in vasomotor modulation in rat superior mesenteric artery. Cardiovasc. Res. 61: 683-692.

10. Kawabata, A., Kuroda, R., Nishikawa, H. and Kawai, K. 1999. Modulation by protease-activated receptors of the rat duodenal motility in vitro: possible mechanisms underlying the evoked contraction and relaxation. Br. J. Pharmacol. 128: 865-872.

11. Kawabata, A., Nishikawa, H., Kuroda, R., Kawai, K. and Hollenberg, M. D. 2000. Proteinase-activated receptor-2 (PAR-2): 
regulation of salivary and pancreatic exocrine secretion in vivo in rats and mice. Br. J. Pharmacol. 129: 1808-1814.

12. Kunieda, K., Someya, A., Horie, S., Ajioka, H. and Murayama, T. 2005. Lafutidine-induced increase in intracellular $\mathrm{Ca}^{2+}$ concentrations in PC12 and endothelial cells. J. Pharmacol. Sci. 97: $67-74$.

13. Mall, M., Gonska, T., Thomas, J., Hirtz, S., Schreiber, R. and Kunzelmann, K. 2002. Activation of ion secretion via proteinase-activated receptor-2 in human colon. Am. J. Physiol. Gastrointest. Liver Physiol. 282: G200-210.

14. Nakayama, T., Hirano, K., Nishimura, J., Takahashi, S. and Kanaide, H. 2001. Mechanism of trypsin-induced endothelium-dependent vasorelaxation in the porcine coronary artery. Br. J. Pharmacol. 134: 815-826.

15. Nguyen, T. D., Moody, M. W., Steinhoff, M., Okolo, C., Koh, D. S. and Bunnett, N. W. 1999. Trypsin activates pancreatic duct epithelial cell ion channels through proteinase-activated receptor-2. J. Clin. Invest. 103: 261-269.

16. Nystedt, S., Emilsson, K., Wahlestedt, C. and Sundelin, J. 1994. Molecular cloning of a potential proteinase activated receptor. Proc. Natl. Acad. Sci. U.S.A. 91: 9208-9212.

17. Ossovskaya, V. S. and Bunnett, N. W. 2004. Protease-activated receptors: contribution to physiology and disease. Physiol. Rev. 84: 579-621.
18. Ozaki, H., Sato, K., Satoh, T. and Karaki, H. 1987. Simultaneous recordings of calcium signals and mechanical activity using fluorescent dye fura 2 in isolated strips of vascular smooth muscle. Jpn. J. Pharmacol. 45: 429-433.

19. Sato, K., Ozaki, H. and Karaki, H. 1988. Changes in cytosolic calcium level in vascular smooth muscle strip measured simultaneously with contraction using fluorescent calcium indicator fura 2. J. Pharmacol. Exp. Ther. 246: 294-300.

20. Sato, K., Ozaki, H. and Karaki, H. 1990. Differential effects of carbachol on cytosolic calcium levels in vascular endothelium and smooth muscle. J. Pharmacol. Exp. Ther. 255: 114-119.

21. Tiruppathi, C., Ahmmed, G. U., Vogel, S. M. and Malik, A .B. 2006. $\mathrm{Ca}^{2+}$ signaling, TRP channels and endothelial permeability. Microcirculation 13: 693-708.

22. Vu, T. K., Hung, D. T., Wheaton, V. I. and Coughlin, S. R. 1991. Molecular cloning of a functional thrombin receptor reveals a novel proteolytic mechanism of receptor activation. Cell 64: 1057-1068.

23. Waldron, R. T., Short, A. D. and Gill, D. L. 1997. Store-operated $\mathrm{Ca}^{2+}$ entry and coupling to $\mathrm{Ca}^{2+}$ pool depletion in thapsigargin-resistant cells. J. Biol. Chem. 272: 6440-6447.

24. Wang, X. and van Breemen, C. 1997. Multiple mechanisms of activating $\mathrm{Ca}^{2+}$ entry in freshly isolated rabbit aortic endothelial cells. J. Vasc. Res. 34: 196-207. 